MaPan : Jurnal Matematika dan Pembelajaran

p-ISSN: 2354-6883 ; e-ISSN: 2581-172X

Volume 8, No 2, Dec 2020 (224-235)

DOI: https://doi.org/10.24252/mapan.2020v8n2a4

\title{
IMPLEMENTATION OF SPACE GEOMETRY LEARNING USING GEOGEBRA TO IMPROVE PROBLEM SOLVING SKILLS
}

\author{
Megita Dwi Pamungkas'), Heny Nugroho') \\ 1,2Program Studi Pendidikan Matematika, FKIP, Universitas Tidar \\ 1,2Jalan Kapten Suparman Nomor 39 Magelang, Jawa Tengah \\ E-mail: megitadwip@untidar.ac.id1), henybebee@gmail.com²)
}

Received September 15, 2020; Revised December 02, 2020; Accepted December 09, 2020

\begin{abstract}
:
Prospective mathematics teachers must be equipped with problem solving skills because it has a very important place in the mathematics curriculum. The purpose of this research is to get an overview of improving the problem solving skills of prospective mathematics teachers by implementing GeoGebra on space geometry learning. The research was conducted in Study Program of Mathematics Education, Tidar University in the second semester students. This research uses quasiexperimental method, with nonequivalent control group pretest-posttest design using two groups, namely experimental group consisting of 36 students got GeoGebrabased space geometry learning and control group consisting of 35 students got conventional space geometry learning. Research instruments in the form of observation sheets and test instruments in the form of pretest and posttest to measure achievements of problem solving skills improvement. The data obtained is then processed and analyzed by calculating the percentage of learning implementation and calculating the average normalized gain score (N-Gain). The results showed that GeoGebra-based Space Geometry learning can improve problem solving skills. In the experimental group, problem solving skills were improved in high category, while in the control group the improvement of problem solving skills in moderate category.
\end{abstract}

Keywords: Space Geometry, GeoGebra, Problem Solving Skills

\section{IMPLEMENTASI PEMBELAJARAN GEOMETRI RUANG BERBASIS GEOGEBRA UNTUK MENINGKATKAN KETERAMPILAN PEMECAHAN MASALAH}

\begin{abstract}
Abstrak:
Calon guru matematika harus dibekali dengan keterampilan pemecahan masalah karena memiliki posisi yang sangat penting dari kurikulum matematika. Tujuan penelitian ini adalah mendapatkan gambaran peningkatan keterampilan pemecahan masalah mahasiswa calon guru matematika dengan mengimplementasikan GeoGebra pada pembelajaran geometri ruang. Penelitian dilaksanakan di Program Studi Pendidikan Matematika Universitas Tidar pada mahasiswa semester II. Penelitian ini menggunakan metode quasi experiment, dengan desain penelitian nonequivalent control group pretest-posttest menggunakan dua kelompok yaitu kelompok eksperimen yang terdiri dari 36 mahasiswa mendapat pembelajaran geometri ruang
\end{abstract}


berbasis GeoGebra dan kelompok kontrol yang terdiri dari 35 mahasiswa mendapat pembelajaran geometri ruang secara konvensional. Instrumen penelitian berupa lembar observasi dan instrumen tes berupa pretest dan posttest untuk mengukur capaian peningkatan keterampilan pemecahan masalah. Data yang diperoleh kemudian diolah dan dianalisis dengan menghitung persentase keterlaksanaan pembelajaran dan menghitung rata-rata skor gain yang dinormalisasi (N-Gain). Hasil penelitian menunjukkan bahwa pembelajaran geometri ruang berbasis GeoGebra dapat meningkatkan keterampilan pemecahan masalah. Di kelompok eksperimen, peningkatan keterampilan pemecahan masalah dalam kategori tinggi, sedangkan pada kelompok kontrol peningkatan keterampilan pemecahan masalah dalam kategori sedang.

Kata Kunci: Geometri Ruang, GeoGebra, Keterampilan Pemecahan Masalah

How to Cite: Pamungkas, M.D., \& Nugroho, H. (2020). Implementation of Space Geometry Learning Using Geogebra to Improve Problem Solving Skills. MaPan : $\begin{array}{llll}\text { Jurnal Matematika dan Pembelajaran, 224-235. } & \text { 8(2), }\end{array}$ https://doi.org/10.24252/mapan.2020v8n2a4.

\section{INTRODUCTION}

7 o become prospective mathematics teachers, students are required to be able to review the concepts that they have obtained during learning to their students in the school later. Therefore, prospective mathematics teachers should be provided with problem solving skills which is one of the must-have skills. This is because problem solving skills can make us think logically, critically, and creatively. Problem solving is recognized as a very important life skill because it involves a variety of processes including analyzing, interpreting, reasoning, predicting, evaluating, and reflecting (Anderson, 2009).

The problem solving skills steps of one of them popularized by Polya (2004) consists of four steps, namely: 1) understanding the problem, 2) devising a plan, 3) implementing the plan, and (4) looking back at the original answer. The National Council of Teachers of Mathematics explained that mathematics problem solving skills need to be developed in mathematics learning (NCTM, 2000). Students should be allowed to implement and adopt the right strategies to solve problems. Therefore, each lesson must be designed to provide students with problem solving skills.

Problem solving skills also have an important place for the primary purpose of a curriculum (Ozturk \& Guven, 2016). In the curriculum of the 
Mathematics Education study program at Tidar University, students are equipped with one of the mandatory courses that are space geometry. This course is very important for students of prospective mathematics teachers because the material is widely found in the curriculum of mathematics subjects taught at the elementary and secondary school levels. Therefore, the student must possess and develop his problem solving skills, considering in his or her job later when becoming a teacher in teaching students to solve mathematics problems. The participation of mathematics teachers in the process of technology integration has been emphasized by encouraging most of their teaching practices and making students learn better in the classroom (Cuban, Kirkpatrick, \& Peck, 2001).

The importance of mathematics problem solving skills on the concept of space geometry for students of prospective mathematics teachers is contrary to the conditions that exist in the field. The results showed that space geometry is a difficult course. Hanafi (2017) shows that geometry learning difficulties are in the high category resulting from a less effective learning process in students of the mathematics education study program in 2009. The same findings were also supported by researchers in initial observations to several prospective mathematics teachers in second-semester who had already received space geometry courses. Preliminary observations showed that students' problem solving skills were still low, with the fact that more than $60 \%$ of students scored less than 70 with a maximum score of 100 . The lack of problem solving skills is caused by the learning process. This is in accordance with the results of interviews with some students of the even semester in 2018/2019 among others: 1) the learning process using more lecture methods, and 2) the learning process has not used technology that is able to provide visualization of materials and concepts.

Space geometry is one of the courses offered in the second semester in the Mathematics Education Study Program, Tidar University. This course is the development and continuation of plane geometry courses. According to the curriculum of the Mathematics Education Study Program, this course contains mathematics objects (points, lines, planes) in space, relationships between geometric objects, planes, limas, prisms, cones, cylinder, spheres, measurements involving objects and shapes of space geometry, space image construction techniques and relationships between objects of space geometry. This standard of learning competency is that students are able to understand and have good space responsiveness, master concepts, and be able to solve 
problems related to building space. In its implementation, there are still many students who solve problems of space geometry learning algorithmically and procedurally (Susilo, Sutarto, \& Mubarok, 2015).

Abramovich (2013) defines GeoGebra as a free online software application for the study of geometry, algebra, and calculus at different grade and teaching levels. GeoGebra is designed to combine dynamic geometry software features (Cabri, Geometer Sketchpad) and computer algebra systems (Derive, Maple) in a single, integrated, and easy-to-use system for teaching and learning mathematics (Hohenwarter, Jarvis, \& Lavicza, 2009). GeoGebra is based on scientific mathematics criteria. GeoGebra has several advantages, including exploring and manipulating various geometric shapes in an activity that students can do by drawing sketches (Stols \& Kriek, 2011). GeoGebra enables teachers to create interactive learning to encourage discovery learning for students while interacting visually on geometry topics. This is a powerful teaching tool for mathematics teachers to provide geometry concepts.

Many studies have discussed GeoGebra, but no one has yet analyzed GeoGebra's relationship with mathematics problem solving skills. Several studies have shown that GeoGebra is able to have a positive impact on students' understanding of concepts (Kurniasih, Wiyanti, \& Zahid, 2018; Lestari, 2018; Mudaly \& Fletcher, 2019). Likewise, some studies have also tried to design space geometry learning, but no one has yet used GeoGebra to apply it to the course (Untarti \& Kusuma, 2018; Wahyuni \& Rahmadhani, 2019).

Based on the above description, a research is needed on the implementation of GeoGebra-based space geometry lectures to improve problem solving skills. The purpose of this research is to get an overview of improving the problem solving skills of prospective mathematics teachers by implementing GeoGebra in space geometry lectures. This research is considered very important to be carried out in order to meet the demands of lecture standards in LPTK (Lembaga Pendidikan Tenaga Kependidikan) to apply learning technology to students of prospective mathematics teacher as well as to facilitate prospective teachers in improving mathematical problem solving skills.

\section{METHODS}

This research used a quasi-experiment, with a research design is a nonequivalent control group pretest-posttest. The study used two groups, one as an experimental group that received GeoGebra-based space geometry 
learning and another group as a control group that got space geometry learning without using GeoGebra. The topics in space geometry discuss cone, cylinder, and sphere. The experiments were conducted 6 times. The design of the research is shown in table 1 .

Table 1. Research Design

\begin{tabular}{cccc}
\hline Experiment & $\mathbf{T}_{1}$ & $\mathbf{X}$ & $\mathbf{T}_{\mathbf{2}}$ \\
\hline Control & $\mathrm{T}_{1}$ & $\mathrm{C}$ & $\mathrm{T}_{2}$ \\
\hline
\end{tabular}

Description:

$\mathrm{T}_{1} \quad=$ pretest of problem solving skills

$\mathrm{X}=$ application of GeoGebra-based space geometry learning

$\mathrm{C}=$ application of conventional method in space geometry learning

$\mathrm{T}_{2} \quad=$ posttest of problem solving skills

The research was conducted Mathematics Education Study Program at Tidar University in the second semester of space geometry learning. The independent variable in this study is GeoGebra-based space geometry learning. The dependent variable is problem solving skill. The instruments employed in this study are tests twice and the observation sheet. Test and observation indicators refer to the problem solving skills indicator reported in table 2 .

Table 2. Description of Aspects and Indicators of Problem Solving Skills

\begin{tabular}{llc}
\hline \multicolumn{1}{c}{ Aspects } & \multicolumn{1}{c}{ Indicators } & Code \\
\hline $\begin{array}{l}\text { Understanding } \\
\text { the problem }\end{array}$ & $\begin{array}{l}\text { 1. Identifying what is known } \\
\text { 2. Determine the asked }\end{array}$ & $\mathrm{U} 1$ \\
& $\begin{array}{l}\text { 1. Create a sketch describing } \\
\text { the problem }\end{array}$ & $\mathrm{D} 1$ \\
& $\begin{array}{l}\text { 2. Determine the right equation } \\
\text { for problem solving }\end{array}$ & $\mathrm{D} 2$ \\
$\begin{array}{l}\text { Implementing } \\
\text { the plan }\end{array}$ & $\begin{array}{l}\text { 1. Substitute the known into an } \\
\text { equation form }\end{array}$ & $\mathrm{I} 1$ \\
Looking back & $\begin{array}{l}\text { 2. Calculate correctly } \\
\text { Evaluate answers based on } \\
\text { concepts }\end{array}$ & $\mathrm{I} 2$ \\
\hline
\end{tabular}


All instruments have gone through a validation process and are declared valid. There are two validators, they are experts in mathematics and mathematics education. The suggestion of validator is an editorial improvement for the problem so as not to cause multi-interpretation. Data analyzed based on answer sheet when subject solves problem and observation sheet. Test instruments in the form of essays use assessment rubrics to measure students' problem solving skills. The test is done before (pretest) and after (posttest) given treatment.

Analysis of problem solving skills improvement data is based on mean, with steps: 1) scoring pretest and posttest results according to the criteria and rubric scoring created then summing up all scores obtained, 2) calculate the average normalized gain score (N-Gain) to determine the increase in problem solving skills, i.e. with criteria a) low if $g<0.3$; b) medium if $0.7>g \geq 0.3$; c) high if $g \geq 0.7$ (Hake, 1999).

\section{RESULTS AND DISCUSSION}

The study used two groups, one as an experimental group that received treatment in the form of GeoGebra-based Space Geometry learning and the other group as a control group that received conventional learning treatment. The learning process was performed in both groups through the following stages: 1) pretest, 2) the provision of conventional treatment for the control group, and the learning to use GeoGebra for the experimental group, and 3) posttest.

The results showed that there was an improvement in space geometry problem solving skills after students learned to use GeoGebra. The results of tests of space geometry problem solving skills can be seen in Table 3. Based on Table 3, an average pretest score of 61.4 and an average posttest score of 93.2 on GeoGebra-based space geometry learning was performed on 36 students. Meanwhile, 35 students scored a pretest average score of 63.6 and a posttest average score of 84.6 .

Table 3. Comparison of Pretest and Posttest Results in Two Groups

\begin{tabular}{cccccccccc}
\hline & \multicolumn{4}{c}{ Experiment } & \multicolumn{4}{c}{ Conventional } \\
\hline & $\mathrm{N}$ & $\mathrm{X}$ & $\langle g\rangle$ & Category & & $\mathrm{N}$ & $\mathrm{X}$ & $\langle g\rangle$ & Category \\
\hline Pretest & 36 & 61.4 & \multirow{2}{*}{0.8} & \multirow{2}{*}{ High } & Pretest & 35 & 63.6 & \multirow{2}{*}{0.57} & Medium \\
Posttest & 36 & 93.2 & & & Posttest & 35 & 84.6 & & \\
\hline
\end{tabular}


Based on table 3, it appears that the posttest average score is higher than the pretest of both learning models. These results indicate that there has been an increase in problem solving skills before and after treatment. Gain normality test results showed that there was an increase of 0.82 for GeoGebrabased space geometry earning, and 0.57 for conventional learning. The higher improvement of the gain normality test shows that learning space geometry using GeoGebra contributes better in improving students' problem solving skills towards space geometry.

The percentage of problem solving skills improvement in the experimental group by $83.3 \%$ for the high category, $16.7 \%$ for the moderate category, and $0 \%$ for the low category. In the control group, the increase was $48.6 \%$ for the high category, $42.8 \%$ in the moderate category, and $8.6 \%$ in the low category. Overall, in the experimental group and the control group together, there are improvements in problem solving skills in space geometry learning that can be seen in figure 1 .

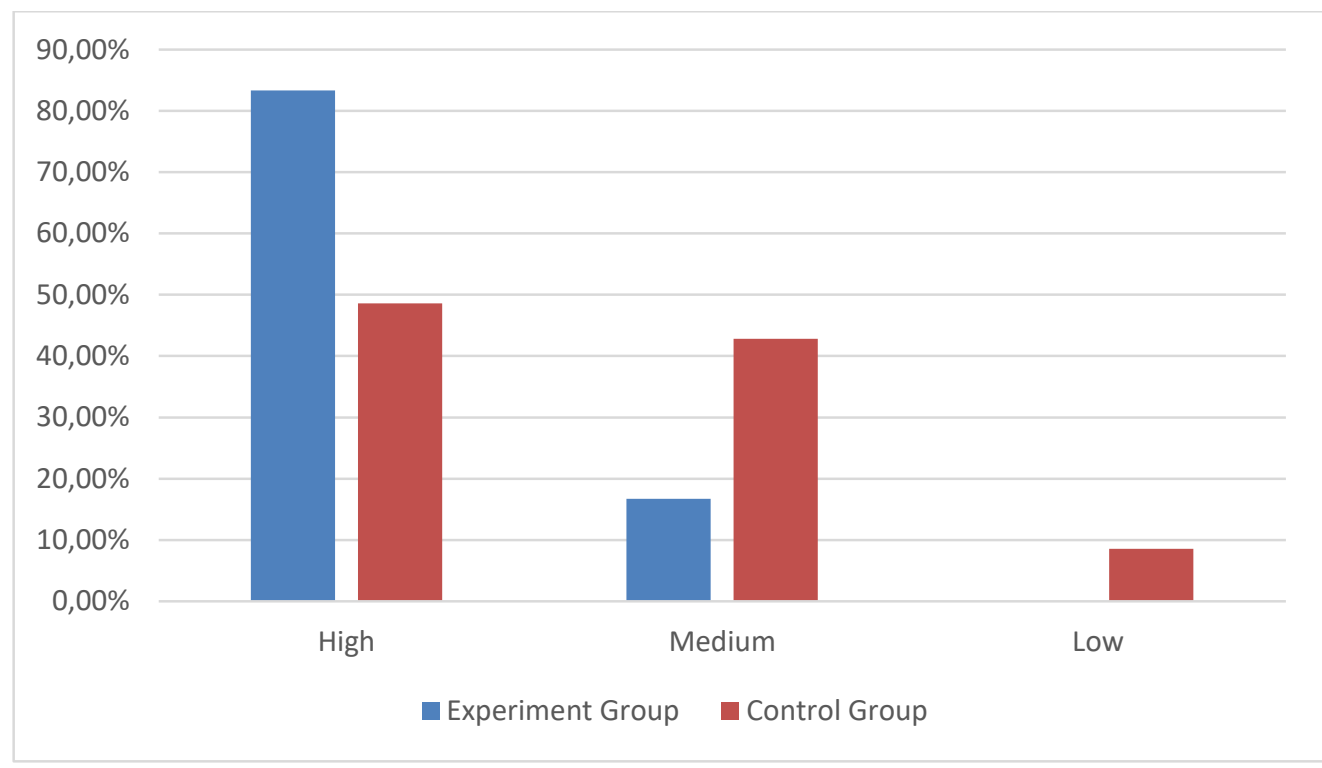

Figure 1. The Percentage of Problem Solving Skills Improvement

Based on the findings of the research, learning space geometry using GeoGebra further improves problem solving skills than conventional learning. Carreira, Jones, Amado, Jacinto, and Nobre (2016) also explained that problem solving is the kind of activity that requires experimentation, exploration, investigation, testing, reflection, and discussion. The results also found that students were able to solve problems very well. Slameto (2010) argues that 
problem solving is seen as a process for determining a combination of several rules that can be applied to resolve a new situation. GeoGebra is an effective tool for teaching and learning space geometry in college because it can improve the achievement of learning space geometry on the topic of plane slices on prism (Pamungkas, Rahmawati, \& Dinara, 2020).

Figure 2 is one of the students' answers in problem solving by using GeoGebra and problem solving skills indicators. Based on the answer sheet in the experimental group, the solving steps are in accordance with indicators of problem solving skills, including U1, U2, D1, D2, I1, I2, and L1. When compared to the answer sheet of the control group in figure 3, it appears that the student does not show a step indicator of problem solving skills, i.e. only D1, D2, I1.
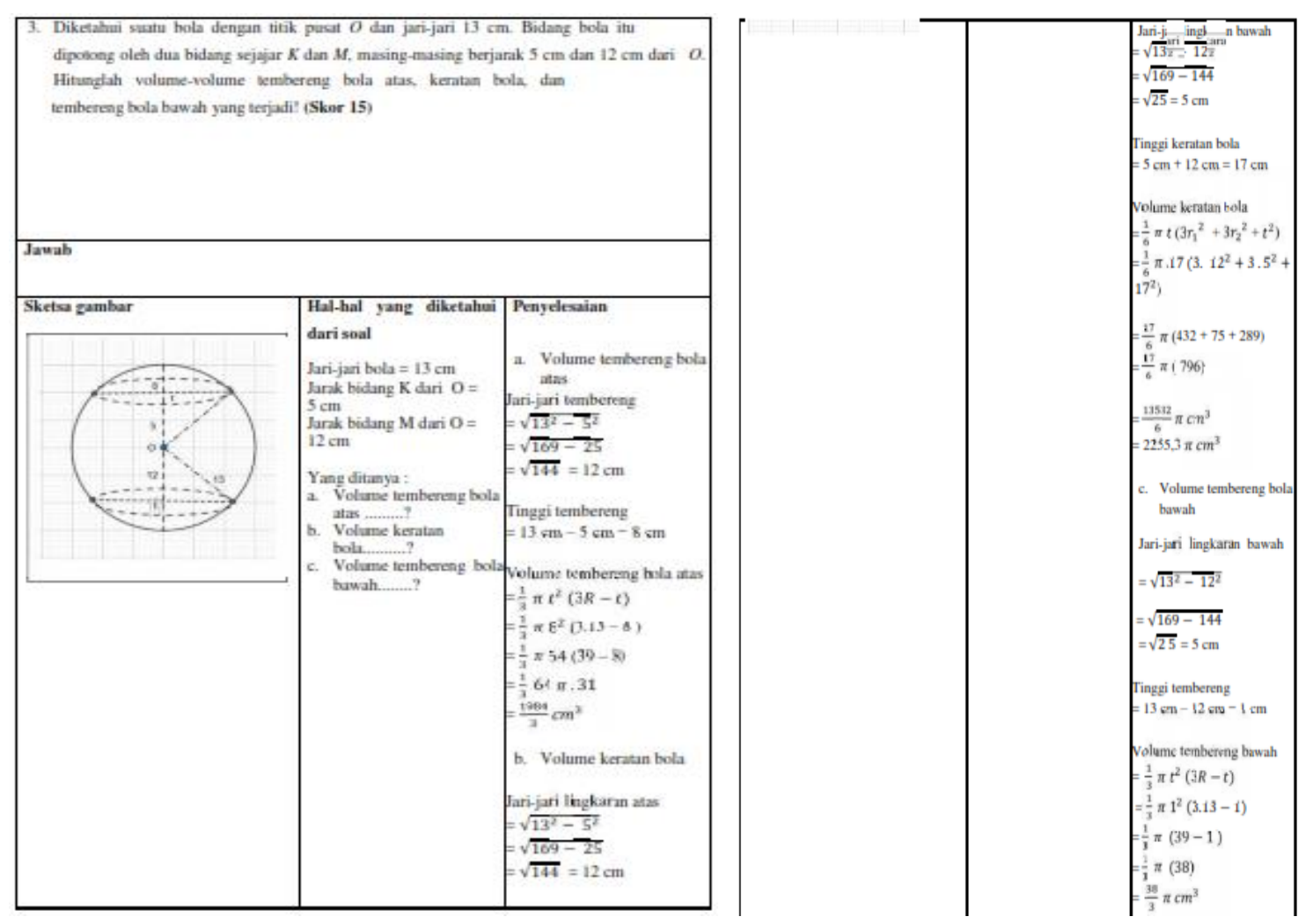

Figure 2. One of the Answer Sheet in the Experimental Group 


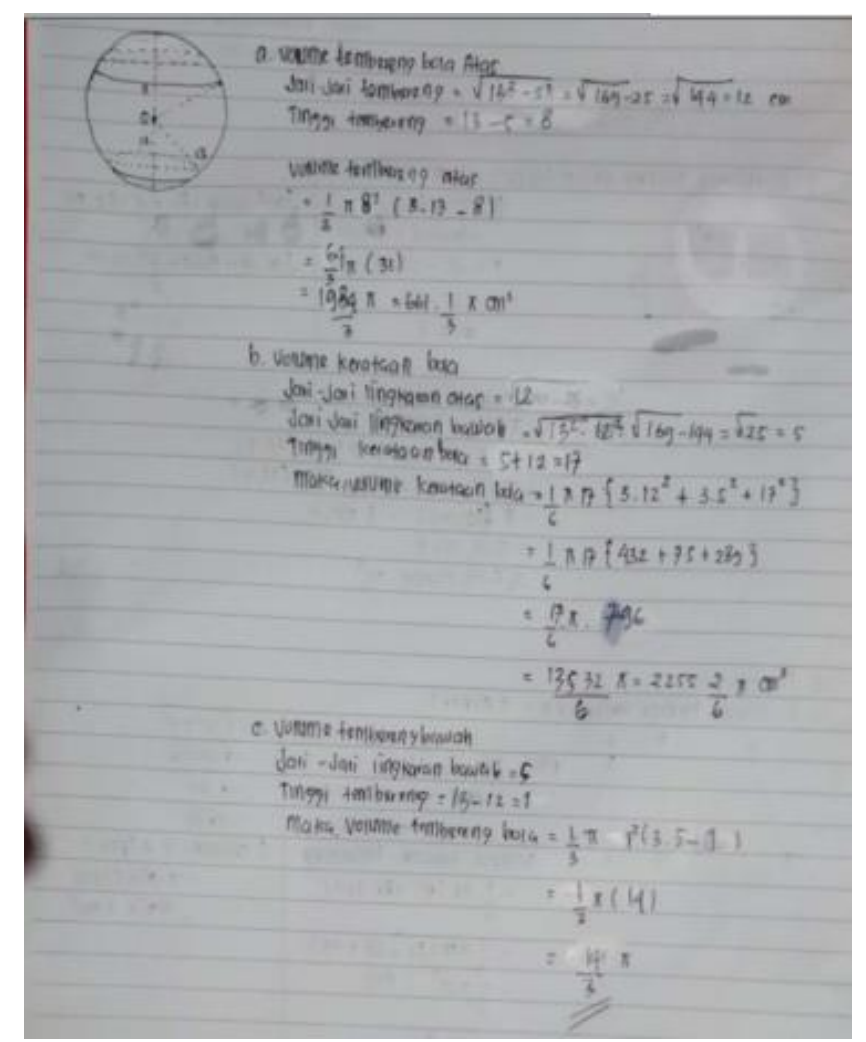

Figure 3. One of the Answer Sheet in the Control Group

GeoGebra can improve students' ability to conceptualize mathematical elements and to improve learning outcomes (Emaikwu, Oche, \& Terseer, 2015). Also, GeoGebra is very useful for demonstrating and visualizing mathematical concepts related, primarily to geometric objects (Mahmudi, 2010). This is supported by the results of research conducted by Saha, Ayub, and Tarmizi (2010) conducting research aimed at identifying the impact of GeoGebra use on the teaching of geometry coordinates on a group of secondary school students. The results showed statistically significant differences between the posttest averages of the two groups in the GeoGebra group. The use of GeoGebra has helped prospective mathematics teachers build new knowledge and connect it with previous knowledge, it is useful in improving problem solving skills (Bhagat \& Chang, 2015).

The results showed that there was an improvement in student problem solving skills during Space Geometry learning in the experimental group and control group. Improvements to GeoGebra learning methods are categorized in high improvement, while conventional learning methods are categorized in moderate category. 


\section{CONCLUSION}

Based on the results and discussions in the research that has been done, it shows that GeoGebra-based space geometry learning can improve problem solving skills. In the experimental group, the increase in problem solving skills in the category was high, while in the control group improved problem solving skills in the medium category. Further research can be focused on the utilization of GeoGebra based on other cognitive aspects. There is an opportunity for further research to explore GeoGebra on other learning materials.

\section{ACKNOWLEDGEMENT}

We would like to thank the Direktorat Riset dan Pengabdian Masyarakat (DRPM), Direktorat Jenderal Penguatan Riset dan Pengembangan of the Ministry of Research, Technology, and Higher Education of the Republic of Indonesia who have funded the implementation of this research.

\section{REFERENCES}

Abramovich, S. (2013). Computers in mathematics education: an introduction. Computers in the Schools, 30(1-2), 4-11. https://doi.org/10.1080/ 07380569.2013 .765305$.

Anderson, J. (2009). Mathematics curriculum development and the role of problem solving. ACSA Conference, 1-8. Sydney: The University of Sydney.

Bhagat, K. K., \& Chang, C. Y. (2015). Incorporating GeoGebra into geometry learning-a lesson from India. Eurasia Journal of Mathematics, Science $\mathcal{E}$ Technology Education, 11(1), 77-86. https://doi.org/ 10.12973/eurasia. 2015.1307a.

Carreira, S., Jones, K., Amado, N., Jacinto, H., \& Nobre, S. (2016). Youngsters solving mathematical problems with technology. New York: Springer.

Cuban, L., Kirkpatrick, H., \& Peck, C. (2001). High access and low use of technologies in high school classrooms: explaining an apparent paradox. American Educational Research Journal, 38(4), 813-834. Retrieved from http:/ / www.jstor.org/stable/3202504.

Emaikwu, Oche, S., \& Terseer, M. (2015). Effect of geogebra on senior secondary school students' interest and achievement in statistics in makurdi local government area of Benue State, Nigeria. Journal of Mathematics (IOSRJM), 14-21. Retrieved from http://www.iosrjournals. org/iosr-jm/papers/Vol11-issue3/Version-4/B011341421.pdf.

Hake, R. R. (1999). Interactive-engagement vs traditional methods: A six thousand student survey of mechanic test data for introductory physics 
courses. Journal of Physics, 66(1), 64-74. https://doi.org/ 10.1119/1.18809.

Hanafi, M. A. (2017). Deskripsi kesulitan belajar geometri mahasiswa program studi pendidikan matematika fakultas keguruan dan ilmu pendidikan Universitas Cokroaminoto Palopo. Seminar Nasional, 273-283. Retrieved from https://www.journal.uncp.ac.id/index.php/proceding/article/ view $/ 797$.

Hohenwarter, M., Jarvis, D., \& Lavicza, Z. (2009). Linking geometry, algebra, and mathematics teachers: geogebra software and the establishment of the international GeoGebra institute. International Journal for Technology in Mathematics Education, 16(2), 83-87. https://www.semanticscholar. org/paper/Linking-Geometry\%2C-Algebra-and-Mathematics-Teachers \%3A-Hohenwarter-Jarvis/f25381390d121df0cb6276af8820f218acc5354b.

Kurniasih, A. W., Wiyanti, D. T., \& Zahid, M. Z. (2018). Visualisasi konsep matematika dalam pembelajaran menggunakan geogebra. PRISMA, Prosiding Seminar Nasional Matematika, 796-799. Retrieved from https://journal.unnes.ac.id/sju/index.php/prisma/article/view/2039.

Lestari, I. (2018). Pengembangan bahan ajar matematika dengan memanfaatkan geogebra untuk meningkatkan pemahaman konsep. GAUSS: Jurnal Pendidikan Matematika, 1(1), 26-36. https://doi.org/10. 30656/gauss.v1i1.634.

Mahmudi, A. (2010). Membelajarkan geometri dengan program GeoGebra. Seminar Nasional Matematika dan Pendidikan Matematika, 469-477. Retrieved from https:/ / eprints.uny.ac.id/10483.

Mudaly, V., \& Fletcher, T. (2019). The effectiveness of geogebra when teaching linear functions using the IPad. Problems of Education in the 21st Century, 77(1), 55-81. https:// doi.org/10.33225/ pec/19.77.55.

NCTM. (2000). Six principles for school mathematics. Reston VA: The National Council of Teachers of Mathematics, Inc.

Ozturk, T., \& Guven, B. (2016). Evaluating students' beliefs in problem solving process: A case study. Eurasia Journal of Mathematics, Science and Technology Education, 12(3), 411-429. https://doi.org/10.12973/eurasia. 2016.1208a.

Pamungkas, M., Rahmawati, F., \& Dinara, H. (2020). Integrating GeoGebra into space geometry in college. Journal of Physics and Conference Series, 1465. https:/ / doi.org/10.2991/assehr.k.200129.123.

Polya, G. (2004). How to solve it. New Jersey: Princeton University Press.

Saha, R. A., Ayub, A. F. M., \& Tarmizi, R. A. (2010). The Effects of geogebra on mathematics achievement: enlightening coordinate geometry learning. Procedia - Social and Behavioral Sciences, 8, 686-693. https://doi.org/ 10.1016/j.sbspro.2010.12.095.

Slameto. (2010). Belajar dan faktor-faktor yang mempengaruhinya. Jakarta: Rineka 


\section{Cipta.}

Stols, G., \& Kriek, J. (2011). Why don't all maths teachers use dynamic geometry software in their classrooms? Australasian Journal of Educational Technology, 27(1), 137-151. https://doi.org/10.14742/ajet. 988.

Susilo, B. E., Sutarto, H., \& Mubarok, D. (2015). Pengembangan perangkat pembelajaran geometri ruang dengan model proving theorem. KREANO: Jurnal Matematika Kreatif-Inovatif, 6(2), 170-176. https://dx. doi.org/10.15294/kreano.v6i2.4979

Untarti, R., \& Kusuma, A. B. (2018). Meningkatkan partisipasi aktif mahasiswa melalui lesson study pada mata kuliah geometri ruang. Jurnal Pendidikan Matematika dan IPA, 9(1), 15-30. https://dx.doi.org/ 10.26418/jpmipa.v9i1.23693.

Wahyuni, S., \& Rahmadhani, E. (2019). Pelatihan penggunaan cabri 3D pada mata kuliah geometri. Jurnal Pengabdian Masyarakat MIPA dan Pendidikan MIPA, 3(1), 1-3. https://doi.org/10.21831/jpmmp.v3i1. 21958. 